\title{
International labour standards and the review of industrial law
}

\author{
Gordon Anderson*
}

This paper examines the major ILO conventions that have a direct bearing on industrial relations structures. After a brief examination of the purposes of ILO standards the New Zealand government's approach to ratification is considered. The paper then looks at the major conventions pointing out the difficulties in implementing them and considering what changes would be needed to New Zealand law to achieve this. The policy and practical implications of such changes are also discussed.

\section{Introduction}

Since 1919, the major source of international labour standards has been the conventions and recommendations of the International Labour Organisation (ILO) together with the interpretative rulings issued by the supervisory bodies established by that organisation. Indeed so significant is this body of international standards that it is often referred to as an international labour code (Valticos, 1979 p. 46). These standards have also been complimented by instruments adopted by other international agencies. notably the United Nations.' but also regional agencies such as the Council of Europe and the League of Arab States.

The ILO conventions are. however. the most important of these instruments because of their world wide application. their sole focus on labour and industrial relations and because they are adopted in the expectation that they will influence the law and practice of member countries to conform to the standards set. The ILO is unique in several aspects. Among international organisations the ILO alone is a tripartite organisation and thus its decisions represent not only the position of governments but also of empioyer and worker delegates. Valticos (1979. p.29) suggests that the tripartite structure "has been an undeniable source of vigour", it avoids decisions being taken in a purely technocratic spirit and gives increased authority to ILO decisions.

Since 1919, the ILO had adopted 161 conventions although a reasonable proportion of these are revisions of earlier conventions. ${ }^{2}$ Of these. New Zealand has ratified $52^{3}$ although 2 of these have been recently denounced. This number of ratifications is reasonably high and compares favourably with an average of 56 ratifications for West European countries.

\section{The nature of and obligation of ILO standards ${ }^{4}$}

ILO standards take the form of either conventions or recommendations. Conventions are

* Senior Lecturer. Department of Accountancy. Victoria University of Wellington.

1 e.g. Universal Declaration of Human Rights (1948); International Covenants on Economic. Social and Cultural Rights (1966) and the International Covenant on Civil and Political Rights (1966).

2 Valticos (1979. pp. 58-59) stated that, in 1978. 40 had been formally revised and another 3 had been supplanted by later Conventions. Since 1978 at least 2 conventions seem to have been revisionary in character.

3 Department of Labour (1982). Since 1982 Conventions 100 and 111 have been ratified. The denounced Conventions are 21 and 89.

4. Valticos (1979) provides a detailed treatment of all aspects of international labour law. 
the more significant of these as they are intended to be formally ratified by member countries. such countries then assuming formal responsibilities to ensure that national law and practice confirms to the convention. To attain the maximum number of ratifications. conventions generally impose only broad minimum standards and attempt to achieve maximum flexibility so as to meet the different social and economic conditions in member countries. Recommendations, on the other hand, are intended only as a guide to practice and policy and do not involve formal legal obligations. There are 166 recommendations at present. For this reason they can be used for a variety of purposes for which a convention may not be suitable. These include providing more detailed and higher standards than may be possible in a convention or providing standards in an area where a convention is not presently possible.

In the case of both conventions and recommendations. member governments of the ILO have an obligation to place the instruments before the competent authority (in New Zealand this is Parliament) and to state the action they propose to take in respect of the instrument. Such action must also be notified to the Director-General of the ILO. New Zealand governments perform this requirement through Parliamentary Papers A7 and A7A. Member countries are also obliged to supply reports on unratified conventions and on recommendations when required. Generally, the ILO Governing Body requires reports on one or more instruments each year. These reports are examined by supervisory bodies.

Ratification of a convention, however, is a formal act by which a state assumes specific legal obligations in respect of the convention. most important of which is the obligation to take such action as may be necessary to make the provisions of the convention effective. Generally these measures are permitted to be flexible and include collective bargaining or similar measures in addition to legislative action. Once ratified. a convention comes into force after 12 months and may only be denounced after a period of 10 years and thereafter only at the end of subsequent 10-yearly periods. Ratification also involves the acceptance of an obligation to provide periodic reports on the measures taken to give effect to the convention and of the possibility of having to answer complaints regarding its observance of a convention. The major supervisory body, the Committee of Experts on the Application of Conventions and Recommendations, consists of persons appointed in their personal capacity and is independent of governments. Freedom of association complaints are dealt with by a separate body, the Committee on Freedom of Association. The decisions of these bodies represent a significant body of law on the application and interpretation of the various conventions.

It should also be noted that. unlike many international instruments, an ILO convention's ratification cannot be made subject to reservations. Consequently ratification may be made more difficult as particular articles which cause problems cannot be avoided even for legitimate reasons.

\section{The New Zealand approach to ratification}

The official New Zealand approach to ratifying ILO conventions has often been stated in its reports on proposed action. "This is: "Because of the obligations incumbent on ratifying countries. New Zealand ratifies a convention only when there is strict compliance of law and practice with all the provisions of the particular Convention". This approach does, however. cause some problems because of the manner in which compliance with a convention is permitted. An article such as:"Effect may be given to this Convention through national laws or regulations or collective agreements, or in any other manner consistent with national practice" (Convention 135, Article 6) is typical of ILO conventions. The dilemma is, of course. that implementation by voluntary procedures such as collective bargaining means that it is difficult for a member state to ensure total compliance. But it is also inconsistent with a system of collective bargaining for the government to dictate the terms of a collective agreement.

That the New Zealand government is aware of this problem can be seen in its response to Convention 144 (on tripartite consultation to promote the implementation of ILO standards) - a most appropriate context in which to make the remarks. The response included the statement that:

5. In Parliamentary Papers A7 and A7A in the Appendix to the Journals of the House of Representatives (AJHR). 
New Zealand has stated in comments to the ILO that it is considered that the subject matter is not one which is suited to an instrument in the form of a Convention. since in our view a Convention is appropriate for topics which require the enactment of legislation or Government direction or supervision. We believe that this particular matter is one in which co-operation from employers' and workers' organisations cannot be enforced. but is to be given voluntarily, and therefore cannot be ensured through legislative or other directive measures. As compliance with the Convention would be dependent upon such cooperation. compliance also cannot be ensured. (AJHR 1975, Paper A7A. p.4).

This approach to ratification would seem to mean that New Zealand may be unable to ratify a convention that requires tripartite co-operation unless universal or virtually universal agreement can be achieved. One consequence is likely to be that only technical conventions will be ratified as normally they can be implemented by government action alone. Those conventions that have broader implications and affect the industrial relations system generally are more likely to require tripartite co-operation and consequently will not be ratified. The conventions to be discussed in this paper are almost all of this type in that they lay down basic principles of industrial relations conduct and their effectiveness depends on tripartite implementation.

The New Zealand government approach is, it can be suggested, unduly conservative. The ILO constitution does not require conformity prior to ratification and the very nature of ILO conventions envisages implementation by means other than government action. Obviously ratification where implementation is unlikely. is not desirable. but in the case of conventions to be implemented by non-governmental measures, ratification should be acceptable where there is substantial compliance. Indeed ratification in such cases should help ensure full compliance especially if the decision to ratify is taken after consultation among all 3 parties. Moreover, given the tripartite membership of the ILO, it can be strongly argued that there is an obligation on both employers and unions to take positive steps to enable ratification. To do otherwise is to avoid responsibility and to undermine the ILO system of tripartite decision making.

While ratification does not directly affect domestic law. which must be changed through normal processes, it may have an influence on judicial decisions. Cooke. $\mathrm{J}$ in Van Gorkon v Attorney General 1 1977] in relation to the United Nations Declaration of Human Rights. said "They may be regarded as representing a legislative policy which might in fluence the courts in the interpretation of statute law."

It is suggested here that the Government should review its policy towards ratification to see if it is possible to ratify the major human rights and industrial relations conventions without the need for prior total compliance.

\section{Conventions relevant to the Green Paper}

ILO conventions cover a multiplicity of subjects, many either technical or confined to specific classes of worker. Only a limited number attempt to lay down general standards for the conduct of industrial relations and the rights and obligations of unions and employers. The most important of these which relate to the Green Paper (which covers only private sector arrangements) are:

(1) Convention 87 : freedom of association and protection of the right to organise (1948)

(2) Convention 98 : applicability of the principles of the right to organise and to bargain collectively (1949)

(3) Convention 135 : protection and facilities to be afforded to workers representatives in the undertaking (1971)

(4) Convention 154 : promotion of collective bargaining (1981).

While these conventions have the broadest implictions, there are other conventions that are relevant to the Green Paper's review such as Convention 158 on termination of employment at the initiative of the employer (1982), which should also be considered by government and others. New Zealand has not ratified any of the above conventions.

The following discussion relates only to the conventions as they apply to private sector arrangements and it does not extend to the recommendations that accompany Conventions 135 and 154. Should it be decided that more positive steps be taken to implement the ILO standards both these matters would require attention. Moreover the discussion focuses only on the main features of the conventions and the problems their implementation would pose. A 
detailed discussion would be both complex and beyond the scope of this paper which is concerned to highlight the problems. not to resolve them in detail.

\section{Freedom of Association (Convention 87)}

Convention 87 is one of the most important of the ILO conventions. It seeks to apply a basic human right and a right central to the constitution of the ILO. The principle was adopted in the original 1919 constitution and affirmed in the Declaration of Philadeplhia 1944. Indeed ILO membership requires adherence to the principle of freedom of association even if Convention 87 has not been ratified. Convention 87 is the only 1 of the 4 conventions covering basic human rights that New Zealand has not ratified. ${ }^{6}$

The failure to ratify Convention 87 relates mainly to the protected position given to unions ${ }^{7}$ under the industrial conciliation and arbitration system. The then Minister of Labour (Hon. J Bolger) speaking to the ILO in 1983 said: "Because of the protective nature of our industrial law New Zealand has yet to ratify the Freedom of Association Convention" (AJHR 19 Paper A7 p.8). The Green Paper does, however, indicate that a movement towards conformity with Convention 87 is envisaged. (Department of Labour. 1985 II p. 276). Such a move seems to be somewhat hesitant as the words "where reasonable" are used. but it is nevertheless to be welcomed. While it would be untrue to argue that the failure to ratify is due to a lack of acceptance of the convention's principles, the failure to ratify does allow the conventions principles to be avoided if convenient for political motives. The Green Paper points out that the failure to ratify meant that no action could be taken in respect of a complaint upheld by the Committee on Freedom of Association relating to the provisions of the Fishing Industry (Union Coverage) Act 1979 (Department of Labour, 1985 I p. 38-39). That the present Government is totally committed to the convention may also be doubted if deregistration threats are made seriously. ${ }^{\mathrm{x}}$

Convention 87 has received much attention in New Zealand during the debate on union membership. a topic that is excluded from the review in any meaningful sense (Department of Labour. 1984. I p. 11-12). Union security clauses are. however, not the central feature of Convention 87. and its implementation raises much wider issues (see Anderson and Brosnan. 1984).

In summary Convention 87 guarantees 4 basic freedoms to workers and employers. These are:

(1) "the right to establish and. subject only to the rules of the organisation concerned, to join organisations of their own choosing" (Article 2).

(2) "the right to draw up their constitutions and rules, to elect their representatives in full freedom. to organise their administration and activities and to formulate their programmes" (Article 3(1).)

(3) "that their organisations shall not be liable to be dissolved or suspended by administrative authority" (Article 4).

(4) "the right to establish and join federations and confederations and the right to affiliate with international organisations" (Article 5).

The convention also prohibits interference with these freedoms by the public authorities. In addition to the convention itself. the main source of guidance on the application of the convention are the decisions of the Committee on Freedom of Association ("the Committee")"

\section{The right to organise}

The right to organise requires that workers should be able to establish and join organisations of their own choosing. This choice may, in practice, be restricted by the unions themselves but what is important is that it must not be restricted by the state. either directly or

6 The others relate to forced labour (No's 29 and 105) and discrimination (No. 111).

7 While the discussion in this part centres on unions much of it also applies to employer bodies.

8 See the comments by the Minister of Civil Aviation in The Dominion, Friday. March 16th. 1985. p. 1.

9 The Committee's decisions are summarised in ILO. 1976. References to decisions refer to the paragraphs of this publication. 
through state-imposed monopolies (para. 16). It follows that the system of monopoly registration in the Industrial Relations Act is contrary to Article 2 in that it is the state and not the union movement itself that defines the structure of the union movement. This seems to have been admitted by the government in reports to the ILO (ILO, 1973, p. 80). The fact that it is legally possible for a union to be formed and operate outside the provisions of the Industrial Relations Act (for example, under the Incorporated Societies Act) would not seem to alter this basic point as registration gives exclusive and unchallengable access to the whole of the conciliation and arbitration system. Unregistered unions may have some access to the system but only in situations where no registered union exists.

An ILO Committee of Experts has commented on this situation as follows:

... where the rights conferred on a registered trade union under an optional system are of such fundamental importance that any organisation deprived of them would have serious difficulty in furthering and defending the interests of its members, the considerations concerning the right to establish organisations "without previous authorisation" are as relevant as in cases in which registration or other formalities are compulsory. (ILO, 1975. p.12)

Any move to ratification must. it seems, result in a major change in the protected status of registered unions. This need not. however, involve a policy of total access to the conciliation and arbitration system. The Committee has accepted the notion of a "most representative" union as long as this does not deprive other unions of the "essential means" of their functioning. The Committee's position is that:

Article 3, paragraph 5. of the Constitution of the ILO states the concepts of "most represenative" organisations. Accordingly the Committee felt that the mere fact that the law of a country draws a distinction between the most representative trade union organisations and other trade union organisations is not in itself a matter for criticism. provided that such distinction does not accord to the most representative organisation privileges extending beyond the privilege of priority. on the ground of its having the largest membership, in representation for such purposes as collective bargaining or consultation by governments or for the purpose of nominating delegates to international bodies. In other words. this distinction should not have the effect of depriving trade union organisations not recognised as being among the most representative of the essential means whereby they may defend the occupational interests of their members, organise their administration and activities and formulate their programmes, as provided for in Convention No, 87 (para. 29).

That provisions may exist to prevent a multiplicity of trade unions has also been recognised by the ILO Committee of Experts (ILO, 1975, p. 17). Again the need for objective criteria to determine the majority union is stressed as is the need to permit at least minimal status to other unions.

For New Zealand law to meet this interpretation it would seem that at least the following changes would be required:

(1) The provisions relating to the legal personality of unions and their constitution needs to be separated from the provisions relating to access to the conciliation and arbitration system.

(2) The criteria for access and the extent of the privileges granted need to be redefined in terms of a most representative union rather than the present system of the first union to register gaining virtually unchallengeable privileges.

This can best be achieved by a separate statute (e.g. a new Trade Unions Act) or by a new part of the Industrial Relations Act which would be appropriate for the incorporation of all unions and which was drafted with unions specifically in mind. Such an approach would also enable a simple solution to problems posed by Articles $3-5$ of the convention to be achieved (see below).

Such a provision need cover only the incorporation and constitutional requirements of unions. That is corporate status, powers and any necessary requirements relating to internal government and management that are compatible with the convention.

The nature of a most representative union has been considered by the Committee which has suggested a number of safeguards (para. 30). These are:

(1) certification to be by an independent body. 
(2) the representative organisation to be chosen by a majority vote of the employees in the unit concerned.

(3) the right of an organisation which fails to secure sufficient votes to ask for a new election after a stipulated period.

(4) the right of an organisation other than the certified organisation to demand a new election after a fixed period.

These safeguards are not exhaustive but are a suggested minimum. It should also be noted that the Committee does not define the appropriate bargaining unit.

It would seem that, within broad safeguards. the bargaining unit and the nature of the most representative union can be defined according to national conditions. The question must therefore be asked: What are the most appropriate arrangements that would be feasible in New Zealand? The answer would reasonably be those that fit most easily within the present structures and institutions. It should be possible, with appropriate modifications, to use the present basis of industry-district registration as the basic unit for the most representative union and grant the privileges accordingly. In most cases this would be unlikely to result in any short-term changes in union organisation and even in the longer term it is likely that agreements within the union movement would limit dramatic change. A transitional period where the present union was designated the most representative would ease the process of change considerably.

While dramatic changes would seem unlikely with a mature union movement, such a revision of the law would involve a marked departure from the present arrangements. As a minimum, existing unions would need to be prepared for other competing unions to operate within their hitherto exclusive preserve, even if only to represent the interests of their own members on a restricted basis. On a more fundamental level, the possibility must exist of a challenge to a union's position and its representative capacity. A well organised and democratic union, responsive to members' needs, should however, have little to fear from such arrangements.

The union movement is in essence left with a choice between its present protected position and a more uncertain position but which gives much stronger guarantees (and international sanctions) to the concept of freedom of association. For a developed union movement the latter option has considerable advantages especially in the light of potential future political developments. The structure of trade unionism in New Zealand has, and in many respects continues to be, seen as a matter for possible political manipulation. Suggestions that unions be reorganised on a plant basis, a reorganisation of major significance, is one manifestation of this. The essence of Convention 87 is that union organisation is a matter for workers and their organisations, not employers or governments.

\section{The right to control their own affairs}

Within present industrial law, New Zealand unions face 3 major impediments to controlling their own affairs; (1) the ultra vires rule; (2) the controls on the membership rules.
(3) the prescriptions on the contents and structure of the union rulebook. Of these, the first 2 are the most significant.

In a line of cases beginning in 1913, the courts have taken a particularly restrictive view of the ultra vires doctrine in relation to trade unions (see Mathieson. 1970 pp. 218-228). In essence, registered unions have been held to have no powers beyond those set out in section 163. i.e. "protect or further the interests of workers engaged in any specified industry," and then possibly only in relation to "industrial matters" as defined in section 2, a section that has been narrowly construed (Anderson, 1979. pp. 3-17). It has, for example, been held that unions have no power to be involved in welfare activities or to amalgamate with organisations outside their own industry, interpretations that would seem totally incompatible with article 3 (and also with real life). The ultra vires rule has also been used by the Registrar to justify a refusal to accept rule changes that widen union activities (Department of Labour, 1985. II pp. 41-42). The Green Paper acknowledges these problems (Department of Labour. 1985. II pp. 52-56) and particularly the narrow scope of the ultra vires rule which it seems to imply could be
widened.

These problems are. however, relatively easy to overcome given the political will. If the
uggestion made above of having a new system of union in suggestion made above of having a new system of union incorporation was adopted it would be relatively simple to include a section defining union powers in a broad manner (cf. 
Companies Act 1955. section 15A) leaving the union itself to decide appropriate limitations.

The second problem. restrictions on membership clauses. could again be overcome. at least legally, by simply allowing unions to incorporate with such contitutions as they see fit within broad parameters set by the legislation. Such an approach would. however. require a major attitudinal change by the unions, although again it could be anticipated that internal union processes would restrict the possibility of major disruption.

Finally. some attention would need to be given to the controls on internal organisation of unions in the Act. Insofar as such provisions are designed to ensure democratic control and to protect members rights (such as Part XIII on election irregularities) or their funds (section 184 on accounts and audits) they are recognised as acceptable. It is only if the controls go beyond this that problems arise. Where controls and safeguards are prescribed it is, however. preferable that abuses are checked by judicial rather than administrative procedures (ILO. 1975. pp. 21-22).

In general then internal controls are acceptable so long as they do not unduly limit union activities. a point the Committee of Experts seem to have specifically noted in connection with New Zealand (ILO. 1973. pp. 80-81).

\section{Freedom from dissolution by administrative action}

It is acknowledged in the Green Paper (Department of Labour 1985. I p. 35) that the deregistration provisions of the Industrial Relations Act are incompatible with Convention 87. The ILO Committee of Experts seems to have agreed with this conclusion in a specific consideration of New Zealand law (ILO, 1973, p. 81). The convention does not. however. prohibit dissolution of unions as such. only the method by which this is achieved. While the Committee accepts dissolution under judicial control as it regards this as providing appropriate safeguards against abuse (para. 157) and further accepts the notion of sequestration of union funds (para 171). it has clearly stated that an unfettered Ministerial power to order the cancellation of the registration of a union is contrary to the convention (para. 161). Sould the ultimate sanction of deregistration (or dissolution) be retained then at least 2 changes are needed. The present unfettered ministerial power needs to be replaced with an appropriate judicial procedure and consequently clear criteria need to be established for justifying deregistration.

Two comments can be made in relation to deregistration. The first is that the need for it has not been clearly established and moreover the availability of alternative procedures (particularly contempt of courts) may well make it unnecessary. Secondly, it should be recognised that deregistration is by nature an anti-union procedure and does not apply to employers in any meaningful way. Indeed the mere suggestion of comparable powers aimed at employers would result in a major howl of outrage.

\section{Right to join federations}

The decision in Auckland Freezing Works IUOW v. New Zealand Freezing Works IAOW (1951) severely restricted the rights of unions to affiliate with larger union groupings. While legislation has ameliorated this position. the position is still somewhat uncertain. Section 198 would still seem to limit international affiliations and possibly affiliation with organisations whose objects exceeded those listed in section 198. The Green Paper acknowledges this problem. which could be solved by a straigtforward amendment to the present law (Department of Labour. 1985. II p. 40).

\section{Right to organise and collective bargaining. (Convention 98)}

This convention. which was adopted in 1949. has 2 main purposes; to protect the right to organise and to promote collective bargaining. As convention 98 also deals with basic rights it is often closely associated with convention 87. The ILO Committee of Experts. for example. in its surveys on freedom of association has considered both conventions together (ILO, 1973: ILO. 1975). This does not. however, mean that the 2 are interdependent and indeed the ILO Committee of Experts has specifically stated this in relation to a New Zealand argument that Convention 98 cannot be ratified because of its close links to Convention 87 (ILO, 1973, p. 82). 


\section{The right to organise}

This right is protected from 2 possible sources of abuse : discrimination against individual workers and attempts by employers to gain domination over unions. Article 1 provides that: (1) Workers shall enjoy adequate protection against acts of anti-union discrimination in respect of their employment.

(2) Such protection shall apply more particularly in respect of acts calculated to:

a. make the employment of a worker subject to the condition that he shall not join a union or shall relinquish trade union membership;

b. cause the dismissal of or otherwise prejudice a worker by reason of union membership or because of participation in union activities outside working hours or. with the consent of the employer, within working hours.

Present New Zealand law gives some protection, explicitly in the victimisation provisions of section 150 and by implication in the personal grievance procedure.

Section 150 is not, however, as explicit as Article 1 and takes a fairly restrictive view of the form of action and range of persons who deserve protection. It seems to relate closely to victimisation in relation to activities within the conciliation and arbitration process rather than to anti-union discrimination, as such (see Szakats and Mulgan. 1985, p. 86). Section 150 (1) (a) is also somewhat ambiguous in that it seems that it may relate only to membership of a formative union rather than an established one.

It is suggested that section 150 could be amended by explicitly providing for the forms of discrimination in Article 1. It may also be that the remedies for dismissal need strengthening to ensure that a union activist cannot be "paid off" by compensation on dismissal by making. reinstatement mandatory in such cases. Such a provision would provide real protection for both the individual and the union. Some dismissal cases suggest that the Arbitration Court may not take fully into account the tensions that can arise in employer-unionist relationships. ${ }^{10}$ The need for protection greater than compensation is recognised by the Committee (para. 215 - 217) and has been acknowledged by the Committee of Experts:

In view of the difficulties which exist to ensure a total and absolute guarantee against acts of anti-union discrimination. in a certain number of countries legislation accords more extensive protection to trade union representatives, who are more usually exposed to acts of such a nature. This special protection is particularly desirable, because in order to be able to perform their trade union duties in full independence, these representatives must have the guarantee that they will not be prejudiced. The guarantee of such protection is also necessary in order to ensure that effect is given to the principle that workers organisations should have the right to elect their representatives in full freedom (ILO, 1973, pp. 64-65).

Present New Zealand law is defective in regard to the protection of union representatives both in scope and in remedies. Article 2 provides:

(1) Workers' and employers' organisations shall enjoy adequate protection against any acts of interference by each other or each other's agents or members in their establishment. functioning or administration.

(2) In particular, acts which are designed to promote the establishment of workers organisations under the domination of employers 'organisations, or to support workers' organisations by financial or other means, with the object of placing such organisations under the control of employers or employers' organisations, shall be deemed to constitute acts of interference within the meaning of this Article.

New Zealand law does not seem to provide specific provisions that fulfil this article's requirements (as the Committee seems in favour; para. 234) although in practice the system of union organisation probably ensures that such domination is unlikely. Nevertheless, specific protection is essential; particularly if there was any move towards smaller-enterprise based unions where such abuses are mostly likely. If the separate incorporation provisions suggested above were adopted, incorporation could be made subject to an independent certification of independence. In practical terms however, the size of the union, in particular the fact that it covers many employees and is financially independent. are probably the best safeguards. These features are retained in the most-representative provisions suggested above. 


\section{Collective bargaining}

The second limb of Convention 98 is found in Article 4:

Measures appropriate to national conditions shall be taken. where necessary. to encourage and promote the full development and utilisation of machinery for voluntary negotiation between employers and employers organisations and workers organisations. with a view to the regulation of terms and conditions of employment by means of collective agreements.

These conventions requirements seem directed more towards ensuring the effective implementation of freedom of association than with a particular method of industrial negotiation. The Australian system is, for example. mentioned by the Committee of Experts (ILO. 1973. p. 72) without adverse comment. Indeed it is noted that the system includes a considerable amount of voluntary negotiation both within and outside the formal system. As the New Zealand system is analogous to that of Australia. and now no longer stipulates compulsory arbitration. it would seem that it is prima facie in conformity with Article 4.

The major concern of Article 4 appears to be that unions are recognised by employers and for the promotion of a bargaining system. In New Zealand. both issues are dealt with by existing law. The conciliation and arbitration system both provides a bargaining system and while not compelling recognition makes it virtually certain.

\section{Workers representatives (Convention 135)}

According to its preamble. this convention is intended to supplement the terms of the antiunion discrimination aspects of Convention 98 with terms in respect of workers representatives. It does so by 2 basic provisions. Article 1 provides:

Workers' representatives in the undertaking shall enjoy effective protection against any act prejudicial to them. including dismissal based on their status or activities as a workers representative or on union membership or participation in union activities. in so far as they act in conformity with existing laws or collective agreements or other jointly agreed arrangements.

Article 2 then provides that representatives be provided with the facilities needed to perform their function:

(1) Such facilities in the undertaking shall be afforded to workers representatives as may be appropriate in order to enable them to carry out their functions promptly and efficiently.

(2) In this connection, account shall be taken of the characteristics of the industrial relations system of the country and the needs, size and capabilties of the undertaking concerned.

(3) The granting of such facilities shall not impair the efficient operation of the undertaking concerned.

Workers" representatives includes union representatives but also representatives "freely elected" by the workers in the undertaking and whose functions do not include activities "recognised as the exclusive prerogative of trade unions" (Article 3). As the latter category is not found in New Zealand at present, the provisions of Article 5 designed to ensure that such representatives do not undermine trade unions, is not relevant.

The New Zealand Government's response to Convention 135 (AJHR. 1973. Paper A7A pp. $2-3$ ) contains only one serious objection to ratification which relates to Article 2 . This is that present law does not provide for "appropriate facilities" to be afforded. a term that is taken to include at least interviewing space. furniture and possibly correspondence facilities. It is recognised that such facilities are often provided in practice but it is argued that legislation would "cut across accepted lines of responsibility". This argument seems somewhat pedantic given the minimal nature of the facilities envisaged and the strong general tendency for legislative intervention in industrial relations. It is suggested that legislation to implement Article 2 would be, at worst, a minimal imposition on employers and, in light of the comments on the tripartite nature of ILO conventions. should be welcomed. This is particularly so if facilities are already widespread in practice. The "facility" of a union "s access to its members is provided in section 96.

The Government's comments suggest that section 150 already covers the requirements of 
Article 1. It has been suggested above, however, that this section needs strengthening and the same comment applies in relation to this convention. The requirements of "effective" protection in particular needs attention. To summarise. Convention 135 could be ratified after minor legal changes, changes that could most appropriately take place within the present review.

\section{Promotion of collective bargaining (Convention 154)}

The preamble to this convention states that "it is desirable to make greater efforts to achieve the objectives" of a number of conventions and recommendations including Conventions 87 and 98 . This object is to be achieved by promoting both the subject matter and the process of collective bargaining. That the convention is regarded as of more than usual significance can perhaps be implied from the implementation provision (Article 4) which. contrary to normal practice, requires implementation by legislation should it not be given effect by other means.

The 2 fundamental provisions are Article 1 which defines collective bargaining in terms of both a process and its subject matter:

For the purpose of this Convention the term "collective bargaining" extends to all negotiations which take place between an employer, a group of employers or one or more employers organisations, on the one hand and one or more workers organisations, on the other. for -

(a) determining working conditions and terms of employment: and/or

(b) regulating relations between employers and workers: and/or

(c) regulating relations between employers or their organisations and workers' organisation or workers organisations:

and article 5 which covers the measures that are to be taken to promote bargaining. The measures can be adapted to national conditions but should have the following aims; (a) collective bargaining should be made possible for all employers and all groups of workers in the branches of activity covered by the Convention; (b) collective bargaining should be progressively extended to all matters covered by subparagraphs (a). (b) and (c) of Article 2 of the Convention; (c) the establishment of rules of procedure agreed between employers' and workers' organisations should be encouraged; (d) collective bargaining should not be hampered by the absence of rules governing the procedure to be used or by the inadequacy or inappropriateness of such rules; (e) bodies and procedures for the settlement of labour disputes should be so conceived as to contribute to the promotion of collective bargaining.

The New Zealand Government has indicated that it will not ratify this convention (AJHR, 1982, Paper A7, p. 51). There seem to be 2 reasons for this. The first is that the matters specified in Article 2 go beyond those included within the definition of "industrial matters" in the Industrial Relations Act. This view is taken because of the restrictive interpretation that has been given to this phrase (see Anderson, 1979, pp. 3-17). It is suggested that this problem should properly be overcome by ensuring that "industrial matters" is given a wider and more natural interpretation, not by refusing to ratify the convention. The argument that defects in New Zealand law are a good reason for refusing to ratify a convention is hardly meritorious. The Green Paper has, however, recognised that the present interpretation of "industrial matters" may be unduly restrictive (Department of Labour. 1985, II pp. 102-103) and presumably implies that reform is required. Any reform should take account of Article 1 of this convention.

The second reason advanced is unclear but it seems to relate a belief that the requirements of Article 4 (on implementation) involve a need to legislate "to require bargaining on matters which are covered by the Convention". The Government regards this as incompatible with its policy of allowing the parties to evolve for themselves the matters on which they wish to negotiate. This objection seems ill-founded. The convention merely states, when defining collective bargaining. that the term "extends to all negotiations ... for" the matters listed. This does not seem to require them all to be bargained for. While the implementation of the convention would make bargaining on these matters possible (or permissible) it would not make it mandatory. This objection would consequently seem to lack substance.

While the conventions title refers to "collective bargaining" it would seem that it envisages that conciliation and arbitration systems come within its scope. Article 6 states that the 
convention does not preclude the operation of systems in which collective bargaining takes place within the framework of conciliation and arbitration.

\section{Conclusion}

A review of those international labour standards that relate to the Green Paper proves to be a useful and salutory exercise. The conventions surveyed in this paper provide what the ILO regards as basic minimum standards and safeguards for the operation of an industrial relations system. That New Zealand has yet to ratify any of these conventions should be seen as a matter of considerable concern. This paper has argued that. in the cases of Convention 98. 135 and 154. there is no substantial barrier to ratification. There are areas where New Zealand law and practice does not conform to these conventions but these are minor and could easily be remedied. The problems are not ones of substance but cases where New Zealand law is inadequate and fails to meet minimum international standards.

If New Zealand takes its obligations to the ILO seriously. it should act to remedy these matters. The reasons government gives for not ratifying often seem to be excuses for inaction rather than reasoned objections to the principles of the conventions. It should be a function of government to actively encourage ratification where possible and to lead unions and employers towards this goal. An impression is given. however. that ILO matters are not given a particularly high priority either by government or the other parties. The general review of industrial relations begun with the Green Paper is an opportunity to change these attitudes and to give proper weight to international standards. both conventions and recommendations.

The failure to ratify convention 87 is perhaps more understandable as there are considerable technical and practical problems to be overcome before conformity could be guaranteed. It is suggested above that these are not insurmountable and that the present review may well be the time to face up to them. However, there also is a strong possibility that the essential nature and purpose of Convention 87 is neither appreciated or accepted. Its basic philosophy is that workers should be able to form and control their own organisations without interference. Legislation such as the Fishing Industry (Union Coverage) Act and suggestions of union restructuring to suit government and employer policies would seem to indicate clearly that this basic philosophy is yet to be fully accepted in New Zealand. Comments that such conventions are aimed only at third world dictatorships, as have been made, are at best arrogant and at heart probably show a lack of sympathy for the Conventions purposes.

The ILO Committee of Experts has stated (ILO. 1973. p. 83) that Conventions 87 and 98 :

\footnotetext{
belong to the category of ILO instruments designed to promote and maintain certain fundamental human rights aimed at safeguarding man's freedom. equality and dignity. As such. they figure among those Conventions which have obtained the largest number of ratifications.
}

That New Zealand is not among this number should be a matter of major concern for a country that prides itself on its liberal and democratic system of government.

\section{References}

Anderson. G (1979) Jurisdiction under the Industrial Relations Act 1973: Some problems and issues Occasional paper in industrial relations No. 24, Victoria University of Wellington.

Anderson. G and Brosnan. P (1984) Freedom of association: New Zealand law and ILO Convention 87 New Zealand law journal. 307-310.

Department of Labour (1982) International labour conventions ratified by New Zealand. Wellington, Government Printer.

Department of Labour (1985) Industrial relations. A framework for review 2 volumes. Wellington. Government Printer.

ILO (1976) Freedom of association: digest of decisions of the Freedom of Association Committee. Geneva. International Labour Office. 
ILO (1973) Freedom of association and collective bargaining: general survey by the Committee of Experts, Report III (4B) 58th Session. International Labour Conference. Geneva, International Labour Office.

ILO (1975) Freedom of association: an International survey, Geneva, International Labour Office.

Mathieson, D (1970) Industrial Law in New Zealand. Wellington, Sweet and Maxwell.

Szakats, A and Mulgan. M (1985) Dismissal and redundancy procedures. Wellington Butterworths.

Valticos, N (1979) International labour law, Deventer, Kluwer.

List of cases

Van Gorkon v Attorney General (1977) 1 NZLR 535.543

Auckland Freezing Works IUOW v New Zealand Freezing Works IAOW (1951) NZLR 314. 